\title{
Novel $\alpha$-Mangostin Derivatives from Mangosteen (Garcinia mangostana L.) Peel Extract with Antioxidant and Anticancer Potential
}

\author{
Vy Anh Tran $\mathbb{D}^{1},{ }^{1,2}$ Thu-Thao Thi Vo $\mathbb{D}^{1,2}$ My-Nuong Thi Nguyen, ${ }^{3,4}$ Nguyen Duy Dat $\mathbb{D},{ }^{5}$ \\ Van-Dat Doan $\mathbb{D D}^{6}{ }^{6}$ Thanh-Quang Nguyen $\mathbb{D D}^{7}$ Quang Hieu Vu $\left(\mathbb{D},{ }^{8}\right.$ \\ Van Thuan Le $\mathbb{D}^{2,9}$ and Thanh Danh Tong $\mathbb{D}^{4,10}$ \\ ${ }^{1}$ Institute of Research and Development, Duy Tan University, Danang 550000, Vietnam \\ ${ }^{2}$ Faculty of Environmental and Chemical Engineering, Duy Tan University, Danang 550000, Vietnam \\ ${ }^{3}$ Department of Genetics, University of Science, Ho Chi Minh City, Vietnam \\ ${ }^{4}$ Vietnam National University, Ho Chi Minh City, Vietnam \\ ${ }^{5}$ Faculty of Chemical \& Food Technology, University of Technology and Education, Thu Duc, Ho Chi Minh City 700000, Vietnam \\ ${ }^{6}$ Faculty of Chemical Engineering, Industrial University of Ho Chi Minh City, 12 Nguyen Van Bao, \\ Ho Chi Minh 700000, Vietnam \\ ${ }^{7}$ Faculty of Technology, Van Lang University, Ho Chi Minh City, Vietnam \\ ${ }^{8}$ NTT Hi-Tech Institute, Nguyen Tat Thanh University, 300A Nguyen Tat Thanh, Ward 13, District 4, Ho Chi Minh City, Vietnam \\ ${ }^{9}$ Center for Advanced Chemistry, Institute of Research and Development, Duy Tan University, Da Nang 550000, Vietnam \\ ${ }^{10}$ Department of Organic Chemistry, Faculty of Chemical Engineering, Ho Chi Minh City University of Technology (HCMUT), \\ 268 Ly Thuong Kiet Street District 10, Ho Chi Minh City, Vietnam
}

Correspondence should be addressed to Vy Anh Tran; trananhvy@duytan.edu.vn, Thu-Thao Thi Vo; vothuthaobd@ gmail.com, Thanh-Quang Nguyen; quang.nguyen@vlu.edu.vn, Quang Hieu Vu; vqhieu@ntt.edu.vn, Van Thuan Le; levanthuan3@duytan.edu.vn, and Thanh Danh Tong; tongdanh@hcmut.edu.vn

Received 24 March 2021; Revised 1 August 2021; Accepted 5 October 2021; Published 21 October 2021

Academic Editor: Marcelino Maneiro

Copyright (C) 2021 Vy Anh Tran et al. This is an open access article distributed under the Creative Commons Attribution License, which permits unrestricted use, distribution, and reproduction in any medium, provided the original work is properly cited.

The mangosteen peels contain biologically active compounds, with antioxidant and anticancer properties. Among these isolated phytochemicals, $\alpha$-mangostin is one of the most powerful natural antioxidants and anticancer compounds. This study focused on synthesizing novel $\alpha$-mangostin $(\alpha-\mathrm{MG})$ derivatives at positions of C-3 and C-6 from extracted $\alpha$-MG of mangosteen peels and investigating antioxidant and anticancer activities. The structures of the synthesized compounds were determined by using MS, ${ }^{1} \mathrm{H}-\mathrm{NMR},{ }^{13} \mathrm{C}-\mathrm{NMR}$, and HPLC. The analysis of the interaction between structure and bioactivity showed that phenol groups on C-3 and C-6 positions play a crucial role in antiproliferative activity to boost both anticancer efficacy and drug-like properties. The antioxidant activity of $\alpha$-MG and its derivatives were investigated by the DPPH method. Among $\alpha$-MG derivatives, 1 -hydroxy-7methoxy-2,8-bis(3-methylbut-2-en-1-yl)-9-oxo-9H-xanthene-3,6-diyl bis(2-bromobenzoate) (compound 4) exhibited significant antioxidant property. The in vitro cytotoxicity against various cancer cell lines (HeLa, MCF-7, NCI-H460, and HepG2) was evaluated by the standard sulforhodamine B assay. The anticancer activities (HeLa, MCF-7, NCI-H460, and HepG2) of compound 4 are five to six times higher than those of $\alpha$-MG and other derivatives. The acetylation at C-3 and C-6 of $\alpha-\mathrm{MG}$ by halogen of benzoyl greatly improved cancer cell toxicity. Our results provide new opportunities for further explorations of $\alpha$-MG derivatives for antioxidant property and promise as drugs in cancer therapy. 


\section{Introduction}

Nowadays, the study of natural phytochemical substances from plants has continuously increased due to their effectiveness in preventing and treating various human diseases [1-4]. These natural substances are an excellent alternative for therapeutic due to abundant resources, low cost, high biocompatibility, nontoxicity to the human body, and high biological and pharmacological activity. Various parts of plants, including roots, stems, leaves, fruits, flowers, and seeds, can be used as sources for the extraction of natural bioactive compounds [5-9]. Many studies have recently focused on the utilization of inexpensive or waste sources from the consumption and food industry for the production of valuable natural substances [2, 10-12]. Additionally, peels of several fruits, e.g., pomegranate, citrus, longan, sapodilla, dragon fruit, banana, and apple, have been reported to be rich in bioactive components (vitamins, flavonoids, and phenolic compounds), which promote high free radical scavenging activity [13-15]. Antioxidants scavenge the oxidants or free radicals created by multiple degenerative and disease processes, e.g., diabetes, cancer, and cardiovascular disorders [12, 16, 17]. Therefore, finding, extraction, and semisynthesis of these active ingredients from traditional medicine play an important role in discovering the new active ingredients in antioxidant, healing, and cancer treatment processes $[4,9,18,19]$.

Mangosteen (Garcinia mangostana L.) is a tropical fruit that can be found in South East Asia, such as Vietnam, Indonesia, Malaysia, and Thailand. This unique fruit is used both in medicine and in cosmetics. The soft and juicy white part inside mangosteen is mainly consumed fresh as dessert. In contrast, the mangosteen peels have been utilized extensively in traditional medicine for treating several illnesses, including skin infection, dysentery, trauma, abdominal pain, and wound infection, as well as cancer treatment [20-22]. The mangosteen peels contain a variety of biologically active compounds (e.g., xanthones, isoflavones, tannins, flavonoids, alpha-, beta-, and gamma-mangostin), exhibiting various biological and medicinal effects such as antioxidant, anti-inflammatory, antimicrobial, and anticancer effects [9, 23-28].

Among these isolated phytochemicals, $\alpha-\mathrm{MG}-(1,3,6-$ trihydroxy-7-methoxy-2,8-bis(3-methyl-2-butenyl)-9H-xanthen9-one) - is one of the most powerful natural antioxidants, and it has recently received great attention to the production of antioxidant and anticancer compounds [29, 30]. Several studies have described the synthesis and medicinal chemistry of $\alpha$-MG derivatives, and evaluation of their therapeutic activity has been reported [31-35]. A diversity of novel xanthone analogs based on $\alpha$-MG was synthesized and tested as anticancer agents by cytotoxic activity using human cancer cell lines [36, 37]. The structure-activity relationship study suggested that the modification of the phenol groups on C3 and C6 of $\alpha$-MG played a critical role in inhibiting cancer cell lines [38]. It was also established that the modification at the $\mathrm{C} 4$ position of $\alpha$-MG increased the anticancer activity and drug-like properties [39]. Besides, the compound having the $\mathrm{Cl}^{-}$group at the $\mathrm{C} 4$ position of $\alpha$-MG showed strong potency and improved solubility many times over $\alpha$-MG [35].

In this study, $\alpha-M G$ was extracted and isolated from mangosteen peels. To improve the antioxidant and anticancer activities of $\alpha-\mathrm{MG}$, a series of new compounds were designed and synthesized from the pristine $\alpha$-MG by simultaneously changing the substituents $\mathrm{OH}$ group on the C-3 and C- 6 of $\alpha-\mathrm{MG}$ by $\mathrm{F}^{-}, \mathrm{Cl}^{-}$, and $\mathrm{Br}^{-}$of benzoyl chloride. $\alpha$-MG derivatives structures were determined using MS, ${ }^{1} \mathrm{H}-\mathrm{NMR},{ }^{13} \mathrm{C}-\mathrm{NMR}$, and HPLC. The antioxidant activity of $\alpha$-MG and its derivatives were investigated by the DPPH method. The effects of cytotoxicity of the synthesized compounds were studied on four cancer cell lines (HeLa, MCF-7, NCI-H460, and HepG2).

\section{Materials and Experiment}

2.1. Chemical Materials. Iodine ( $\geq 99.8 \%$, solid), tetrahydrofuran (THF) (anhydrous, $\geq 99.9 \%)$, chloroform $(\geq 99 \%)$, sulfuric acid (95.0-98.0\%), dichloromethane ( $\geq 99.8 \%)$, 4fluorobenzoyl chloride (98\%), 3-fluorobenzoyl chloride (98\%), 2-fluorobenzoyl chloride (99\%), 2-bromobenzoyl chloride (98\%), 3-bromobenzoyl chloride (98\%), 4-bromobenzoyl chloride (98\%), 3-chloromobenzoyl chloride (98\%), L-glutamine (98\%), amphotericin B $(250 \mu \mathrm{g} / \mathrm{mL}$ in deionized water), 4-(2-hydroxyethyl)-1-piperazineethanesulfonic acid (HEPES) ( $\geq 99.5 \%)$, penicillin $G$ (96.0-102.0\%), streptomycin ( 1 mg/mL in $1 \mathrm{mM}$ EDTA), camptothecin ( $\geq 90 \%$ (HPLC), powder), dimethyl sulfoxide (DMSO) ( $\geq 99 \%)$, sulforhodamine B (powder, BioReagent), and acetic acid ( $\geq 99 \%)$ were purchased from Sigma Aldrich, Singapore. TLC Silica Gel 60 F254 plates $(20.0 \mathrm{~cm} \times 10.0 \mathrm{~cm})$ were purchased from Merck. Silica Gel 230-400 mesh for column chromatography was bought from Himedia (India). Other chemicals were used by the highest commercially available quality as provided. Ethanol and water were used without further purification. Glassware was cleaned by the solution of $\mathrm{HNO}_{3}: \mathrm{HCl}(1: 3 \mathrm{v} / \mathrm{v})$.

\subsection{Methods of Characterization}

2.2.1. Thin-Layer Chromatography (TLC). TLC was carried out on F254 silica gel plates with the mobile phase of ethyl acetate: hexane $(\mathrm{E}: \mathrm{H})$ at different ratios $(1: 9,2: 8,3: 7,4: 6$, $5: 5) .5 \mu \mathrm{L}$ of standard solution and samples were spotted on a TLC plate, cut to $10 \mathrm{~cm} \times 10 \mathrm{~cm}$, and then placed into a glass chamber that was previously saturated with the mobile phase for $15 \mathrm{~min}$. After the mobile phase reached the upper limit (a distance of $8 \mathrm{~cm}$ ), the plate was removed from the chamber, dried in air at room temperature, and then observed under visible light or UV light [40].

2.2.2. Column Chromatography (CC). CC was used to fractionate and purify $\alpha-\mathrm{MG}$ and its derivatives using a glass column (diameters of $1.5,2$, and $5 \mathrm{~cm}$; length of 30 and $40 \mathrm{~cm}$ ) filled with silica gel of 230-400 mesh. A solvent mixture of $\mathrm{E}: \mathrm{H}$ in a ratio of $20: 80$ was used as the mobile phase [41]. 
2.2.3. High-Performance Liquid Chromatography (HPLC). HPLC was conducted at RT on the Agilent 1260 Infinity HPLC system equipped with a DAD-detector using the C-18 analytical column $(250 \mathrm{~mm} \times 4.6 \mathrm{~mm}, 5 \mu \mathrm{m})$ and a $20 \mu \mathrm{L}$ injection volume with a flow rate of $1 \mathrm{~mL} / \mathrm{min}$ [42]. The standard stock solutions of $\alpha$-MG and $\alpha$-MG derivatives were set by dissolving accurately weighed compounds in methanol to make a concentration of $1 \mathrm{mg} / \mathrm{mL}$. All samples were held at $4^{\circ} \mathrm{C}$ and brought to room temperature before use. The mobile phase consisted of $0.1 \%$ solution of phosphoric acid in water (solution A) and methanol (solution B). Solution gradient mode was as follows: (i) at 0 minutes: $30 \%$ of solution A, $70 \%$ of solution B; (ii) at 15 minutes: $100 \%$ of solution B; and (iii) at 20 minutes: $100 \%$ of solution B.

2.2.4. Mass Spectrometry (MS) and Magnetic Resonance Spectroscopy $\left({ }^{1} H-N M R,{ }^{13} C-N M R\right)$. The structure of $\alpha$-MG and its derivatives were determined by $\mathrm{MS},{ }^{13} \mathrm{C}-\mathrm{NMR}$, and ${ }^{1} \mathrm{H}-\mathrm{NMR}$ spectra were determined on MicroOTOF-Q 10187 mass spectrometer (Brucker, Germany) and 500 Ultrashield NMR Spectrometer (Brucker, Germany).

2.3. Extraction of $\alpha-M G$. Fresh mangosteen fruits were obtained from the Mekong river delta in Vietnam. The fullyripe fruits (dark purple peel) were selected for the study. The pieces of mangosteen peels were dried in a hot air oven at $45 \pm 0.5^{\circ} \mathrm{C}$ and then ground into a fine powder. Typically, $500 \mathrm{~g}$ of powdered mangosteen peel was soaked into $1 \mathrm{~L}$ of ethyl acetate at room temperature $\left(25^{\circ} \mathrm{C}\right)$ for $96 \mathrm{~h}$. The solid fraction was separated from the extract by filtration; TLC preliminarily determined the presence of $\alpha$-MG in the extract. The filtered mangosteen peel powder was further soaked into ethyl acetate solvent 2 times for $96 \mathrm{~h}$ to extract the remaining $\alpha$-MG. Next step, the obtained extract was mixed with the silica gel and put into the evaporating flask to evaporate ethyl acetate resulting in $\alpha$-MG powder. The condensed extract was partitioned with $n$-hexane to remove indeterminate compounds that were soluble in n-hexane. Then, the ratio of ethyl acetate was gradually added to the mixture, so that the $\mathrm{E}: \mathrm{H}$ ratio increased from $1: 99$ to $30: 70$. The mixture containing $\alpha$-MG was isolated by CC. The processes of mixing the silica gel, evaporation, and isolation were repeated until obtaining pure $\alpha$-MG (tested by TLC and HPLC as well as NMR spectra). The yield percentage was calculated from the weight ratio of $\alpha-M G$ and the dry raw material [43].

\subsection{Synthesis of $\alpha-M G$ Derivatives at $C 3$ and $C 6$}

2.4.1. Synthesis of $\alpha-M G$ Derivatives from 2-Fluorobenzoyl Chloride, 3-Fluorobenzoyl Chloride, and 4-Fluorobenzoyl Chloride (Compounds 1, 2, and 3). $100 \mathrm{mg}$ of $\alpha$-MG $(0.2 \mathrm{mM})$ dissolved in $5 \mathrm{~mL} \mathrm{CH} \mathrm{Cl}_{2}$ was mixed with $0.1 \mathrm{~mL}$ $(0.6 \mathrm{mM})$ of trimethylamine at room temperature. Then, $0.07 \mathrm{~mL}(0.6 \mathrm{mM})$ of 2-fluorobenzoyl chloride or 3-fluorobenzoyl chloride or 4-fluorobenzoyl chloride was added to the mixed solution under magnetic stirring $(500 \mathrm{rpm})$ at room temperature $(25 \mathrm{C})$. The reaction was tracked by TLC to determine the change of the initial substance $(\alpha-\mathrm{MG})$ and the newly formed substances after 48 or 60 or $55 \mathrm{~h}$, respectively. The light-yellow liquid of the formed compounds (compounds 1,2, and 3) was isolated by CC using a solvent mixture of $\mathrm{E}: \mathrm{H}=20: 80$, respectively.

2.4.2. Synthesis of $\alpha-M G$ Derivatives from 2-Bromobenzoyl Chloride and 4-Bromobenzoyl Chloride (Compounds 4 and 5). A mixture of $\alpha-\mathrm{MG}(100 \mathrm{mg}, 0.2 \mathrm{mM})$, trimethylamine $(0.1 \mathrm{~mL}, 0.6 \mathrm{mM})$, and $5 \mathrm{~mL}$ of $\mathrm{CH}_{2} \mathrm{Cl}_{2}$ was stirred for $30 \mathrm{~min}$ at room temperature. Then, 2-bromobenzoyl chloride $(0.08 \mathrm{~mL}, 0.6 \mathrm{mM})$ or 4 -bromobenzoyl chloride $(133.9 \mathrm{mg}$, $0.6 \mathrm{mM})$ was added and stirred $(600 \mathrm{rpm})$ at room temperature for 50 or 65 hours, respectively. After determining very faint traces of $\alpha$-MG by TLC, the yellow powder of newly formed substances (compounds 4 and 5) was isolated by $\mathrm{CC}$ using the mobile phase of $\mathrm{E}: \mathrm{H}=20: 80$, crystallized and dried, respectively.

2.4.3. Synthesis of $\alpha-M G$ Derivative from 3-Chlorobenzoyl Chloride (Compound 6). $100 \mathrm{mg}$ of $\alpha-\mathrm{MG}(0.2 \mathrm{mM})$ previously dissolved in $5 \mathrm{~mL} \mathrm{CH} \mathrm{CH}_{2} \mathrm{Cl}_{2}$ was reacted with 3-chlorobenzoyl chloride $(0.07 \mathrm{~mL}, 0.6 \mathrm{mM})$ in the presence of $0.10 \mathrm{~mL}$ of trimethylamine at room temperature for $50 \mathrm{~h}$. The formation of a new compound was followed by TLC. The yellow powder of a new compound (compound 6) was purified by silica gel CC with the mobile phase of $\mathrm{E}: \mathrm{H}=20$ : 80.

\subsection{Biological Evaluation}

2.5.1. Antioxidant Activity Evaluation. The antioxidant activity of $\alpha$-MG and its derivatives were investigated by using 1,1-diphenyl-2-picrylhydrazyl (DPPH) assay [44]. The scavenging behavior tests the antioxidant potential to capture the DPPH radical by donating a hydrogen atom. By antioxidants quenching the DPPH radical, the DPPH solution changes its color to light yellow from deep violet, and the absorbance decreases at $517 \mathrm{~nm}$. Ascorbic acid was used as the reference for evaluating the antioxidant activity of $\alpha-\mathrm{MG}$ and its derivatives. The concentration of the working DPPH solution was $6 \mathrm{mM}$ prepared by dissolving DPPH in methanol, and the concentration of the sample solutions was varied at $0.1,0.5$, and $1.0 \mathrm{mg} / \mathrm{mL} .100 \mu \mathrm{L}$ of DPPH $(6 \mathrm{mM})$ was dropped into $2.8 \mathrm{~mL}$ methanol, followed by adding $100 \mu \mathrm{L}$ of every sample solution. The resultant solution was shaken at RT for 30 min before the absorption was measured at $517 \mathrm{~nm}$ on a Cary $60 \mathrm{UV}$-Vis spectrophotometer (Agilent, USA). The scavenging activity of the synthesized compounds was calculated using

$$
Q(\%)=\frac{A_{0}-A}{A_{0}} \times 100 .
$$

$Q(\%)$ is the percentage of the scavenging activity of the compound, $\mathrm{A}$ is the absorbance in the presence of the tested compound, and $A_{\mathrm{o}}$ is the absorbance without sample. 
2.5.2. Cell Culture, Growth Conditions, and Treatments. MCF-7 (human breast cancer cells, ATCC \#HTB-22), HeLa (human cervical cancer cells, ATCC \#CCL-2), NCI-H460 (human large-cell lung carcinoma cells, ATCC \#HTB-177), and Hep G2 cells (human hepatocellular carcinoma cells, ATCC \#HB-8065) were cultured in Eagle's Minimal Essential Medium (EMEM) added to 10\% FBS (v/v), $20 \mathrm{mM}$ HEPES, $2 \mathrm{mML}$-glutamine, $100 \mathrm{IU} / \mathrm{mL}$ penicillin $G$, $0.025 \mu \mathrm{g} / \mathrm{mL}$ amphotericin $\mathrm{B}$, and $100 \mu \mathrm{g} / \mathrm{mL}$ streptomycin and maintained at $37^{\circ} \mathrm{C}$ in a humidified incubator with $5 \%$ $\mathrm{CO}_{2}$.

DMSO was dissolved in the camptothecin and synthesized compounds at the concentrations of $2,4,6,8$, and $10 \mu \mathrm{g} / \mathrm{mL}$. The camptothecin, an anticancer compound, was used as a positive control. The control group has only been handled under similar conditions with DMSO.

2.5.3. In Vitro Cytotoxicity of $\alpha-M G$ Derivatives. The 4 kinds of tested cells were seeded in 96-well microtiter plates at a density of $7.5 \times 10^{3}$ cells per well (NCI-H460) or $10 \times 10^{3}$ cells per well (MCF-7, HeLa, and Hep G2) for 24 hours before incubation about $48 \mathrm{~h}$ with various concentrations of the compounds. When the incubation ends, cells were fixed with cold trichloroacetic acid $50 \%(\mathrm{w} / \mathrm{v})$ for $1.5 \mathrm{~h}$; then, plates were washed 5 times with $\mathrm{H}_{2} \mathrm{O}$. The plate was stained with $0.2 \%(\mathrm{w} / \mathrm{v})$ sulforhodamine B for 20 minutes [45, 46]. The protein-bound dye was solubilized in $10 \mathrm{mM}$ Tris base solution after five washes with $1 \%$ acetic acid. The absorbance was measured at a wavelength of $492 \mathrm{~nm} / 620 \mathrm{~nm}$ with the microplate reader (Synergy HT, BioTek, Vermont, USA). The growth inhibition percentage (Inh \%) was determined by

$$
\operatorname{Inh} \%=\left(1-\left(\left[\frac{\mathrm{ODt}}{\mathrm{ODc}}\right] \times 100\right)\right) \%,
$$

in which ODc and ODt are the values of the optical density of the control sample and test sample, respectively. A drug concentration is needed for inhibition of $50 \%\left(\mathrm{IC}_{50}\right)$, which was calculated by GraphPad Prism ver 5 .

\section{Results and Discussion}

The previous studies have reported several semisynthetic amphiphilic $\alpha$-MG derivatives as potential compounds for in vitro bactericidal activity on Gram-positive bacteria (Figure 1). $\alpha$-MG, $\beta$-MG, and $\gamma$-MG can kill bacteria quickly and avoid the phenomenon of drug resistance (Figure 1(a)) $[49,50]$. Besides, the synthetic and medicinal chemistry of $\alpha$-MG derivatives for the activity of anticancer was recorded. Xanthone analogs based on $\alpha$-MG were carried out and estimated as an anticancer compound by an in vitro cell test. A variety of compounds have shown promising activity on cancerous cell lines (compounds i, ii, and iii in Figure 1(b)). These studies suggest that C-3 and C-6 phenol groups are critical to inhibiting cancer cell lines and increase the activity of drug-like properties [51-53].
3.1. Extraction, Isolation of $\alpha-M G$, and Chemical Reactions. $\alpha$-MG yields obtained from $500 \mathrm{~g}$ of dried mangosteen peel corresponded to $0.56 \%(2.813 \mathrm{~g})$ and moisture content of $\alpha$-MG of $19.94 \pm 0.06 \%$. After isolation by CC technology with the solvent mixture of $\mathrm{E}: \mathrm{H}$, the $\alpha-\mathrm{MG}$ yield was $1.321 \mathrm{~g}$. The extractable performance was $0.26 \%$.

The following are the yield, analytical data, and spectra data for each compound:

$\alpha-M G$. Yellow powder (Figure S1), yield: $90.8 \%,{ }^{1} \mathrm{H}-$ NMR $\left(500 \mathrm{MHz}, \mathrm{CDCl}_{3}\right) \delta 13.78(\mathrm{~s}, 1 \mathrm{H}), 6.28(\mathrm{~s}, 1 \mathrm{H})$, $6.30(\mathrm{~s}, 1 \mathrm{H}), 6.83(\mathrm{~s}, 1 \mathrm{H}), 6.14(\mathrm{~s}, 1 \mathrm{H}), 3.46(\mathrm{~d}$, $J=11.5 \mathrm{~Hz}, 2 \mathrm{H}), 5.17-5.22(\mathrm{~m}, 1 \mathrm{H}), 1.70(\mathrm{~s}, 3 \mathrm{H}), 1.84(\mathrm{~s}$, $3 \mathrm{H}), 4.10(\mathrm{~d}, J=10.5 \mathrm{~Hz}, 2 \mathrm{H}), 5.23-5.27$ (m, $1 \mathrm{H}), 1.85$ $(\mathrm{s}, 3 \mathrm{H}), 1.78(\mathrm{~s}, 3 \mathrm{H}), 3.81(\mathrm{~s}, 3 \mathrm{H})$ (Figure $\mathrm{S} 1$ ) and (Table S1).

HPLC (DAD, C-18), peak area: 96.81\%, $T_{\mathrm{R}}: 11.90 \mathrm{~min}$.

$\alpha-M G$ derivative from 2-fluorobenzoyl chloride (1-hydroxy-7-methoxy-2,8-bis(3-methylbut-2-en-1-yl)-9-oxo9H-xanthene-3,6-diyl bis(2-fluorobenzoate) (1)). Yellow powder (Figure S1), yield: $87.2 \%,{ }^{1} \mathrm{H}-\mathrm{NMR}(500 \mathrm{MHz}$, $\left.\mathrm{CDCl}_{3}\right) \delta 13.47(\mathrm{~s}, 1 \mathrm{H}), 7.30(\mathrm{~s}, 1 \mathrm{H}), 6.80(\mathrm{~s}, 1 \mathrm{H}), 3.41$ $(\mathrm{d}, J=7.0 \mathrm{~Hz}, 2 \mathrm{H}), 5.20(\mathrm{~m}, 1 \mathrm{H}), 1.62(\mathrm{~s}, 3 \mathrm{H}), 1.71$ (s, $3 \mathrm{H}), 4.19(\mathrm{~d}, J=6.5 \mathrm{~Hz}, 2 \mathrm{H}), 5.25(\mathrm{~m}, 1 \mathrm{H}), 1.85(\mathrm{~s}, 3 \mathrm{H})$, $1.63(\mathrm{~s}, 3 \mathrm{H}), 3.82(\mathrm{~s}, 3 \mathrm{H}), 7.28-7.32(\mathrm{~m}, 2 \mathrm{H}), 7.66(\mathrm{~m}$, $1 \mathrm{H}), 7.63(\mathrm{~m}, 1 \mathrm{H}), 7.24(\mathrm{~m}, 1 \mathrm{H}), 7.23(\mathrm{~m}, 1 \mathrm{H}), 8.12-5.15$ $(\mathrm{m}, 2 \mathrm{H})$ (Figure S1) and (Table S2).

${ }^{13} \mathrm{C}-\mathrm{NMR}\left(125 \mathrm{MHz}, \mathrm{CDCl}_{3}\right) \delta 161.57,116.51,163.48$, $100.48,153.80,110.76,154.14,146.93,139.34,117.09$, $182.99,107.31,154.92,22.38,121.33,132.35,25.62$, $17.68,26.53,122.67,132.38,18.21,25.82,61.91,161.15$, 149.34, 117.45 (d, $J=8.9), 117.20(\mathrm{~d}, J=8.9), 117.48$, 117.30, 135.88(d, J= 9.1), 135.57 (d, $J=8.9), 124.38$ (d, $J=3.5), 124.22(\mathrm{~d}, J=3.9), 132.83,132.66$ (Figure S3) and (Table S2).

HRMS (ESI-MS, $\mathrm{m} / \mathrm{z}), \quad(\mathrm{M}+\mathrm{Na})^{+}$, $\left[\mathrm{C}_{38} \mathrm{H}_{32} \mathrm{~F}_{2} \mathrm{O}_{8}+\mathrm{Na}\right]^{+}$, theory: 677.1957, experiment: 677.1958 (Figure S4).

HPLC (DAD, C-18), peak area: 94.81\%, $T_{\mathrm{R}}: 28.87 \mathrm{~min}$.

$\alpha-M G$ derivative from 3-fluorobenzoyl chloride (1-hydroxy-7-methoxy-2,8-bis(3-methylbut-2-en-1-yl)-9-oxo9H-xanthene-3,6-diyl bis(3-fluorobenzoate) (2)). Yellow powder (Figure S1), yield: $88.9 \%,{ }^{1} \mathrm{H}-\mathrm{NMR}(500 \mathrm{MHz}$, $\left.\mathrm{CDCl}_{3}\right) \delta 13.47(\mathrm{~s}, 1 \mathrm{H}), 6.78(\mathrm{~s}, 1 \mathrm{H}), 7.30(\mathrm{~s}, 1 \mathrm{H}), 3.39$ $(\mathrm{d}, J=6.5 \mathrm{~Hz}, 2 \mathrm{H}), 5.18(\mathrm{~m}, 1 \mathrm{H}), 1.61(\mathrm{~s}, 3 \mathrm{H}), 1.71(\mathrm{~s}$, $3 \mathrm{H}), 4.19(\mathrm{~d}, J=6.5 \mathrm{~Hz}, 2 \mathrm{H}), 5.24(\mathrm{~m}, 1 \mathrm{H}), 1.85(\mathrm{~s}, 3 \mathrm{H})$, $1.62(\mathrm{~s}, 3 \mathrm{H}), 3.81(\mathrm{~s}, 3 \mathrm{H}), 7.91(\mathrm{~m}, 1 \mathrm{H}), 7.88(\mathrm{~m}, 1 \mathrm{H})$, $7.54(\mathrm{~m}, 1 \mathrm{H}), 7.53(\mathrm{~m}, 1 \mathrm{H}), 7.39(\mathrm{~m}, 1 \mathrm{H}), 7.37$ (ms, 1H), $8.05(\mathrm{~m}, 1 \mathrm{H}), 8.02(\mathrm{~m}, 1 \mathrm{H})$ (Figure S2) and (Table S3).

${ }^{13} \mathrm{C}-\mathrm{NMR}\left(125 \mathrm{MHz}, \mathrm{CDCl}_{3}\right) \delta 162.78,116.49,163.13$, $100.40,153.83,110.70,154.14,146.89,139.41,117.11$, $182.95,107.33,155.07,22.38,121.34,132.47,25.62$, $17.80,26.53,122.57,132.49,18.22,25.83,61.97$, $161.14,149.45,131.13$ (d, $J=7.6), 130.74$ (d, $J=7.8)$, $117.28(\mathrm{~d}, J=9.4), 117.10(\mathrm{~d}, J=9.6), 163.66$ (d, $J=7.0), 161.71(\mathrm{~d}, J=6.8), 121.33(\mathrm{~d}, J=21.1), 121.55$ (d, $J=20.0), 130.55$ (d, $J=7.6), 130.37$ (d, $J=7.6$ ), 


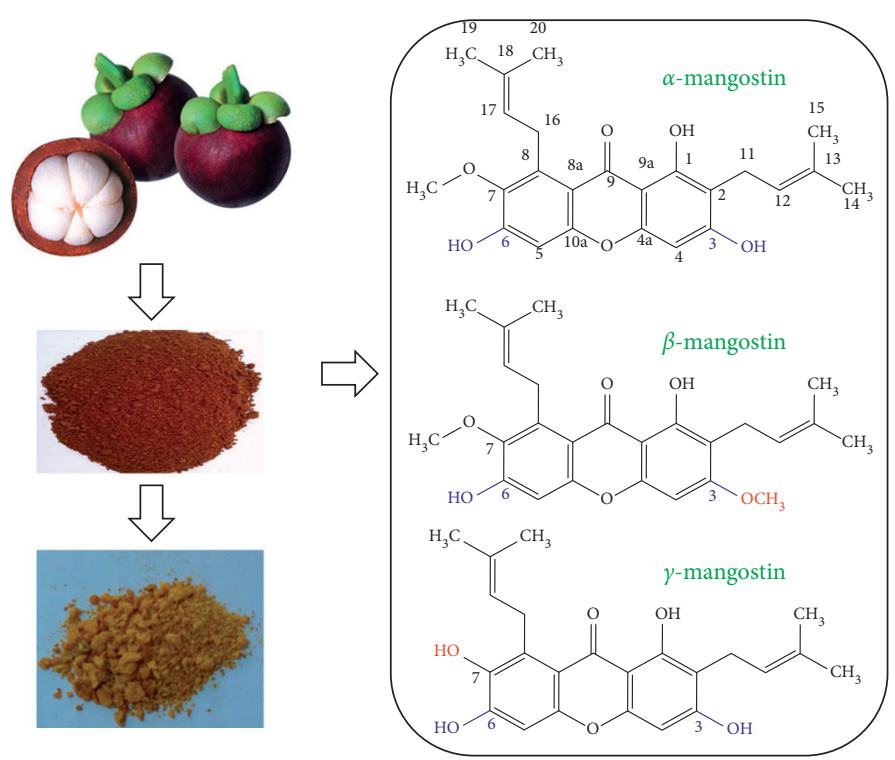

(a)

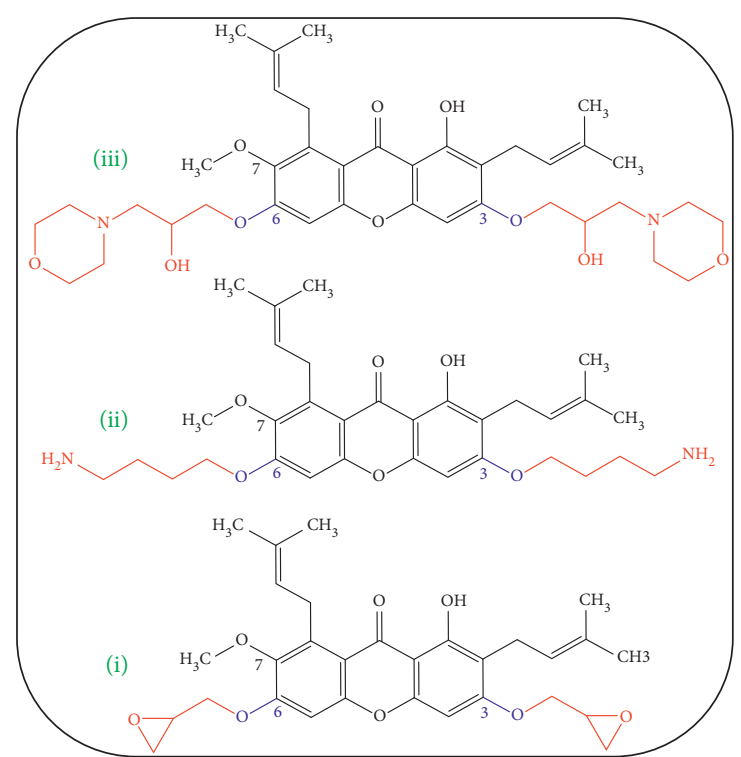

(b)

Figure 1: (a) Structures of $\alpha$-MG and its natural derivatives, including $\beta$-MG and $\gamma$-MG. (b) Examples of $\alpha$-MG derivatives at position C3 and C6 with biological activity [47]. (i) 1-Hydroxy-7-methoxy-2,8-bis(3-methylbut-2-en-1-yl)-6-(((R)-oxiran-2-yl)methoxy)-3-(((S)oxiran-2-yl)methoxy)-9H-xanthen-9-one, (ii) 3,6-bis(4-aminobutoxy)-1-hydroxy-7-methoxy-2,8-bis(3-methylbut-2-en-1-yl)-9Hxanthen-9-one, and (iii) 3,6-bis(4-(diethylamino)butoxy)-1-hydroxy-7-methoxy-2,8-bis(3-methylbut-2-en-1-yl)-9H-xanthen-9-one $[48,49]$.

$126.15(\mathrm{~d}, J=2.9), 126.04(\mathrm{~d}, J=2,9)$ (Figure S3) and (Table S3).

HRMS (ESI-MS, $\mathrm{m} / z),(M+H)^{+},\left[\mathrm{C}_{38} \mathrm{H}_{32} \mathrm{~F}_{2} \mathrm{O}_{8}+\mathrm{H}\right]^{+}$, theory: 655.2138, experiment: 655.2134 (Figure S4).

HPLC (DAD, C-18), peak area: $94.45 \%, T_{\mathrm{R}}: 19.38 \mathrm{~min}$.

$\alpha-M G$ derivative from 4-fluorobenzoyl chloride (1-hydroxy-7-methoxy-2,8-bis(3-methylbut-2-en-1-yl)-9-oxo9H-xanthene-3,6-diyl bis(4-fluorobenzoate) (3)). Yellow powder (Figure S1), yield: 82.5\%, ${ }^{1} \mathrm{H}-\mathrm{NMR}(500 \mathrm{MHz}$, $\left.\mathrm{CDCl}_{3}\right) \delta 13.48(\mathrm{~s}, 1 \mathrm{H}), 6.77(\mathrm{~s}, 1 \mathrm{H}), 7.26(\mathrm{~s}, 1 \mathrm{H}), 3.38$ $(\mathrm{d}, J=7.0 \mathrm{~Hz}, 2 \mathrm{H}), 5.17(\mathrm{~m}, 1 \mathrm{H}), 1.60(\mathrm{~s}, 3 \mathrm{H}), 1.71(\mathrm{~s}$, $3 \mathrm{H}), 4.18(\mathrm{~d}, J=6.5,2 \mathrm{H}), 5.24(\mathrm{~m}, 1 \mathrm{H}), 1.85(\mathrm{~s}, 3 \mathrm{H}), 1.61$ $(\mathrm{s}, 3 \mathrm{H}), 3.78(\mathrm{~s}, 3 \mathrm{H}), 8.25-8.27(\mathrm{~m}, 2 \mathrm{H}), 8.23-8.25(\mathrm{~m}$, $2 \mathrm{H}), 7.26-7.28(\mathrm{~m}, 2 \mathrm{H}), 7.21-7.23(\mathrm{~m}, 2 \mathrm{H})$ (Figure $\mathrm{S} 2$ ) and (Table S4).

${ }^{13} \mathrm{C}-\mathrm{NMR}\left(125 \mathrm{MHz}, \mathrm{CDCl}_{3}\right) \delta 162.92,116.52,163.25$, $100.46,153.83,116.75,154.15,146.95,139.31,117.02$, $182.96,107.27,155.18,22.39,121.39,132.37,25.63$, $17.80,26.52,122.63,132.39,18.21,25.82,61.92,161.11$, $149.56,125.25,124.88,132.98,132.40,133.10,133.03$, $116.04,115.86,116.22,116.04,167.45$ (d, $J=19.25)$, $165.42(\mathrm{~d}, J=19.38)$ (Figure S3) and (Table S4).

HRMS (ESI-MS, $\mathrm{m} / \mathrm{z}), \quad(\mathrm{M}+\mathrm{Na})^{+}$, $\left[\mathrm{C}_{38} \mathrm{H}_{32} \mathrm{~F}_{2} \mathrm{O}_{8}+\mathrm{Na}\right]^{+}$, theory: 677.1957, experiment: 677.1953 (Figure S4).

HPLC (DAD, C-18), peak area: 95.39\%, $T_{\mathrm{R}}: 18.82 \mathrm{~min}$.

$\alpha-M G$ derivative from bromobenzoyl chloride (1-hydroxy-7-methoxy-2,8-bis(3-methylbut-2-en-1-yl)-9-oxo9H-xanthene-3,6-diyl bis(2-bromobenzoate) (4)). Yellow powder (Figure S1), yield: $86.4 \%,{ }^{1} \mathrm{H}-\mathrm{NMR}$ $\left(500 \mathrm{MHz}, \mathrm{CDCl}_{3}\right) \delta 13.48(\mathrm{~s}, 1 \mathrm{H}), 6.83(\mathrm{~s}, 1 \mathrm{H}), 7.33(\mathrm{~s}$, $1 \mathrm{H}), 3.41(\mathrm{~d}, J=6.5 \mathrm{~Hz}, 2 \mathrm{H}), 5.19(\mathrm{~m}, 1 \mathrm{H}), 1.64(\mathrm{~s}, 3 \mathrm{H})$, $1.71(\mathrm{~s}, 3 \mathrm{H}), 4.19(\mathrm{~d}, J=6 \mathrm{~Hz}, 2 \mathrm{H}), 5.25(\mathrm{~m}, 1 \mathrm{H}), 1.86(\mathrm{~s}$, $3 \mathrm{H}), 1.64(\mathrm{~s}, 3 \mathrm{H}), 3.82(\mathrm{~s}, 3 \mathrm{H}), 7.76-7.79(\mathrm{~m}, 2 \mathrm{H})$, 7.47-7.49 (m, 2H), 7.45-7.46 (m, 2H), 8.07-8.12 (m, $2 \mathrm{H})$ (Figure S2) and (Table S5).

${ }^{13} \mathrm{C}-\mathrm{NMR}\left(125 \mathrm{MHz}, \mathrm{CDCl}_{3}\right) \delta 162.94,116.56,163.32$, $100.34,153.82,110.73,154.13,146.99,139.42,117.12$, $182.94,107.32,154.96,22.41,121.34,132.39,25.67$, $17.80,26.56,122.67,132.50,18.23,25.81,61.07,161.18$, $149.31,132.60,132.00,122.80,122.71,134.99,134.89$, $133.71, \quad 133.50, \quad 130.57, \quad 130.24, \quad 127.48, \quad 127.36$ (Figure S3) and (Table S5).

HRMS (ESI-MS, m/z), $(M+H)^{+},\left[\mathrm{C}_{38} \mathrm{H}_{32} \mathrm{Br}_{2} \mathrm{O}_{8}+\mathrm{H}\right]^{+}$, theory: 799.0339, experiment: 799.0353 (Figure S4). HPLC (DAD, C-18), peak area: 96.68\%, $T_{\mathrm{R}}: 19.18 \mathrm{~min}$.

$\alpha-M G$ derivative from 4-bromobenzoyl chloride (1-hydroxy-7-methoxy-2,8-bis(3-methylbut-2-en-1-yl)-9-oxo9H-xanthene-3,6-diyl bis(4-bromobenzoate) (5)). Yellow powder (Figure S1), yield: $89.4 \%$, ${ }^{1} \mathrm{H}-\mathrm{NMR}$ $\left(500 \mathrm{MHz}, \mathrm{CDCl}_{3}\right) \delta 13.48(\mathrm{~s}, 1 \mathrm{H}), 6.77(\mathrm{~s}, 1 \mathrm{H}), 7.28(\mathrm{~s}$, $1 \mathrm{H}), 3.37(\mathrm{~d}, J=7 \mathrm{~Hz}, 2 \mathrm{H}), 5.16(\mathrm{~m}, 1 \mathrm{H}), 1.55(\mathrm{~s}, 3 \mathrm{H})$, $1.71(\mathrm{~s}, 3 \mathrm{H}), 4.18(\mathrm{~d}, J=6 \mathrm{~Hz}, 2 \mathrm{H}), 5.23(\mathrm{~m}, 1 \mathrm{H}), 1.84(\mathrm{~s}$, $3 \mathrm{H}), 1.60(\mathrm{~s}, 3 \mathrm{H}), 3.77(\mathrm{~s}, 3 \mathrm{H}), 7.71(\mathrm{~s}, 1 \mathrm{H}), 7.69(\mathrm{~s}, 1 \mathrm{H})$, $7.69(\mathrm{~s}, 1 \mathrm{H}), 7.68(\mathrm{~s}, 1 \mathrm{H}), 8.11(\mathrm{~s}, 1 \mathrm{H}), 8.09(\mathrm{~s}, 1 \mathrm{H}), 8.08$ (s, 1H), $8.06(\mathrm{~s}, 1 \mathrm{H})$ (Figure S2) and (Table S6).

${ }^{13} \mathrm{C}-\mathrm{NMR}\left(125 \mathrm{MHz}, \mathrm{CDCl}_{3}\right) \delta 163.23,116.49,163.56$, $100.42,153.82,110.71,154.14,146.89,139.36,117.06$, $182.94,107.30,155.09,22.38,121.34,132.44,25.64$, $17.84,26.53,122.58,132.44,18.22,25.84,61.94$, 
$161.12,149.48,129.61,129.28,132.28,132.11,131.80$, 131.73, 127.89, 127.52 (Figure S3) and (Table S6). HRMS (ESI-MS, m/z), $(\mathrm{M}+\mathrm{H})^{+},\left[\mathrm{C}_{38} \mathrm{H}_{32} \mathrm{Br}_{2} \mathrm{O}_{8}+\mathrm{H}\right]^{+}$, theory: 799.0339, experiment: 799.0317 (Figure S4). HPLC (DAD, C-18), peak area: 95.20\%, $T_{\mathrm{R}}$ : $21.82 \mathrm{~min}$.

$\alpha-M G$ derivative from 3-chlorobenzoyl chloride (1-hydroxy-7-methoxy-2,8-bis(3-methylbut-2-en-1-yl)-9-oxo9H-xanthene-3,6-diyl bis(3-chlorobenzoate) (6)). Yellow powder (Figure S1), yield: $79.5 \%,{ }^{1} \mathrm{H}-\mathrm{NMR}$ $\left(500 \mathrm{MHz}, \mathrm{CDCl}_{3}\right) \delta 13.76(\mathrm{~s}, 1 \mathrm{H}), 6.78(\mathrm{~s}, 1 \mathrm{H}), 7.29$ (s, $1 \mathrm{H}), 3.41(\mathrm{~d}, J=6.5 \mathrm{~Hz}, 2 \mathrm{H}), 5.17(\mathrm{~m}, 1 \mathrm{H}), 1.61(\mathrm{~s}, 3 \mathrm{H})$, $1.71(\mathrm{~s}, 3 \mathrm{H}), 4.19(\mathrm{~d}, J=6 \mathrm{~Hz}, 2 \mathrm{H}), 5.24(\mathrm{~m}, 1 \mathrm{H}), 1.85$ (s, $3 \mathrm{H}), 1.62(\mathrm{~s}, 3 \mathrm{H}), 3.79(\mathrm{~s}, 3 \mathrm{H}), 8.19-8.22(\mathrm{~m}, 2 \mathrm{H})$, 7.76-7.79 (m, 2H), 7.49-7.51 (m, 2H), 8.10-8.12 (m, 2H) (Figure S2) and (Table S7).

\footnotetext{
${ }^{13} \mathrm{C}-\mathrm{NMR}\left(125 \mathrm{MHz}, \mathrm{CDCl}_{3}\right) \delta 162.74,116.50,163.05$, $100.39,153.84,110.68,154.14,146.91,139.43,117.14$, $182.95,107.34,155.06,22.38,121.35,132.46,25.61$, $17.80,26.54,122.58,132.50,18.21,25.82,62.00$, $161.15,149.43,130.76$ và $130.36,130.36,130.31$, $135.10,134.94,134.21,133.95,130.15,130.00,128.47$, 128.38 (Figure S3) and (Table S7).

HRMS (ESI-MS, m/z), $(\mathrm{M}+\mathrm{H})+,\left[\mathrm{C}_{38} \mathrm{H}_{32} \mathrm{Cl}_{2} \mathrm{O}_{8}+\mathrm{H}\right]^{+}$, theory: 709.1366, experiment: 709.1366 (Figure S4). HPLC (DAD, C-18), peak area: 96.51\%, $T_{\mathrm{R}}: 21.52 \mathrm{~min}$.
}

The synthetic procedure to obtain the $\alpha$-MG derivatives compounds is shown in Figure 2. The natural compound, $\alpha-\mathrm{MG}$, reacted with 2-fluorobenzoyl chloride, 3-fluorobenzoyl chloride, and 4-fluorobenzoyl chloride in the presence of trimethylamine using dichloromethane solvent to obtain compounds 1, 2, and 3, respectively. Subsequently, $\alpha$-MG was treated with 2-bromobenzoyl chloride, 4-bromobenzoyl chloride with the solvent of dichloromethane, and the presence of trimethylamine to form $\alpha$-MG derivatives of 4 and 5. Next, also $\alpha$-MG reacted with 3 -chlorobenzoyl chloride under the same conditions to provide compound 6 . The chemical structures were determined by ${ }^{1} \mathrm{H}-\mathrm{NMR},{ }^{13} \mathrm{C}-\mathrm{NMR}, \mathrm{MS}$, and HPLC. A relevant synthesis and analytical data were provided in the experimental section and supporting information.

3.2. Evaluation of Antioxidant Activity. The free radical scavenging potential of $\alpha-\mathrm{MG}$ and its derivatives at different concentrations were also detected by the DPPH assay [54]. Compounds 1, 2, and 6 showed a weak antioxidant activity even at high concentrations of $1 \mathrm{mg} / \mathrm{mL}$, which are lower than those of $\alpha$-MG. The antioxidant activity of compounds 1,2 , and 6 at $1.0 \mathrm{mg} / \mathrm{mL}$ was $7.1 \%, 3.8 \%$, and $5.9 \%$, respectively, and lower than that of $\alpha-\mathrm{MG}(8 \%)$. In the case of compound 3, the antioxidant activity increased slightly to $12.2 \%$ at a concentration of $1.0 \mathrm{mg} / \mathrm{mL}$. For compound 5 , the antioxidant activity at a concentration of $0.1,0.5$, and $1 \mathrm{mg} /$ $\mathrm{mL}$ was $6.2,12.7$, and $13.6 \%$, respectively, which were higher than those of $\alpha$-MG. Significantly, the antioxidant activity of compound 4 climbed up to $18.2,43.3$, and $68.7 \%$ at $0.1,0.5$, and $1.0 \mathrm{mg} / \mathrm{mL}$, respectively, and these values were far beyond those of $\alpha$-MG and remaining derivatives, as shown in Figure 3.

In this study, the data indicated that $\alpha-M G$ and its derivatives could be free radical inhibitors, which may be assigned to hydroxyl groups at C-3 and C-6. The phenolic compounds may attribute these antioxidant functions to their hydrogen-donating capacity. The free radicals induce autoxidation of unsaturated lipids. Antioxidants inhibit the free oxidation radical chain reaction in transferring hydrogen from the phenolic hydroxyl groups, creating a stable end compound. The difference in the antioxidant activity of $\alpha$ - MG derivatives could be due to different positions of $\mathrm{Cl}^{-}$, $\mathrm{F}^{-}$, and $\mathrm{Br}^{-}$onto the chemical structure of benzoyl, as reported by previous studies on the relationship between chemical structures and DPPH antioxidant activity [55].

\subsection{In Vitro Cytotoxicity against Cancerous Cell Lines.} Based on the outstanding results of antioxidant activity, compound 4 was selected for in vitro cytotoxicity against human cancer cell lines. To investigate the anticancer activity of compound 4, the cytotoxicity assay was performed in MCF-7, NCI-H460, HeLa, and Hep G2 cancerous cells for $48 \mathrm{~h}$. As shown in Figure 4, 19.1, 20.6, and 29.3\% of NCI-H460 cells die after being treated by compound 4 with a corresponding concentration of 2,4 , and $6 \mu \mathrm{g} / \mathrm{mL}$. This result indicated the high sensitivity of NCI-H460 cancerous cells toward compound 4, even at low concentrations. Besides, compound 4 showed lower cytotoxicity for HeLa and MCF-7 cell lines than for NCI-H460. At low concentrations (2, 4, and $6 \mu \mathrm{g} / \mathrm{mL})$, compound 4 exhibited insignificant cytotoxicity against Hep G2 cancerous cells.

However, almost cell of Hep G2 was killed by compound 4 at the concentration of $10 \mu \mathrm{g} / \mathrm{mL}$. Meanwhile, the lower cytotoxic percentage for the remaining cancerous cell lines was signified at $10 \mu \mathrm{g} / \mathrm{mL}$. The cytotoxicity for MCF-7, HeLa, and NCI-H460 corresponded to the values of $68.5,77.4$, and $88.5 \%$. These results indicated that compound 4 could notably kill four cancerous cell lines at a concentration of $10 \mu \mathrm{g} /$ $\mathrm{mL}$. And this result is significantly higher than that of $\alpha-\mathrm{MG}$ as shown in Figure S5.

To measure the potency of compound 4 in inhibiting four cancerous cell lines, the half-maximal inhibitory concentration $\left(\mathrm{IC}_{50}\right)$ was evaluated. As shown in Figure 5, $\alpha$-MG and compound 4 inhibited the tested cancer cell lines, including MCF-7, NCI-H460, HeLa, and Hep G2. Generally, compound 4 exhibited significant cytotoxicity toward all measured cancer cell lines with $\mathrm{IC}_{50}$ values significantly smaller than $\alpha$-MG. For $\alpha-\mathrm{MG}, \mathrm{IC}_{50}$ results reached the highest value of $26.86 \mu \mathrm{g} / \mathrm{mL}$ for Hep G2 and the lowest value of $19.59 \mu \mathrm{g} / \mathrm{mL}$ for NCI-H460 cancerous cell line. Regarding MCF-7 and HeLa cell lines, $\mathrm{IC}_{50}$ values corresponded to 19.90 and $24.88 \mu \mathrm{g} / \mathrm{mL}$.

Compound 4 showed moderate cytotoxicity against Hep G2, NCI-H460, and MCF-7 cells with $\mathrm{IC}_{50}$ values of 9.12, 8.82 , and $8.47 \mu \mathrm{g} / \mathrm{mL}$, respectively. Moreover, the $\mathrm{IC}_{50}$ values of compound 4 against HeLa cell lines were the lowest at $7.45 \mu \mathrm{g} / \mathrm{mL}$. Thus, compound 4 was significantly cytotoxic against the four kinds of cancerous cell lines than $\alpha-\mathrm{MG}$. 


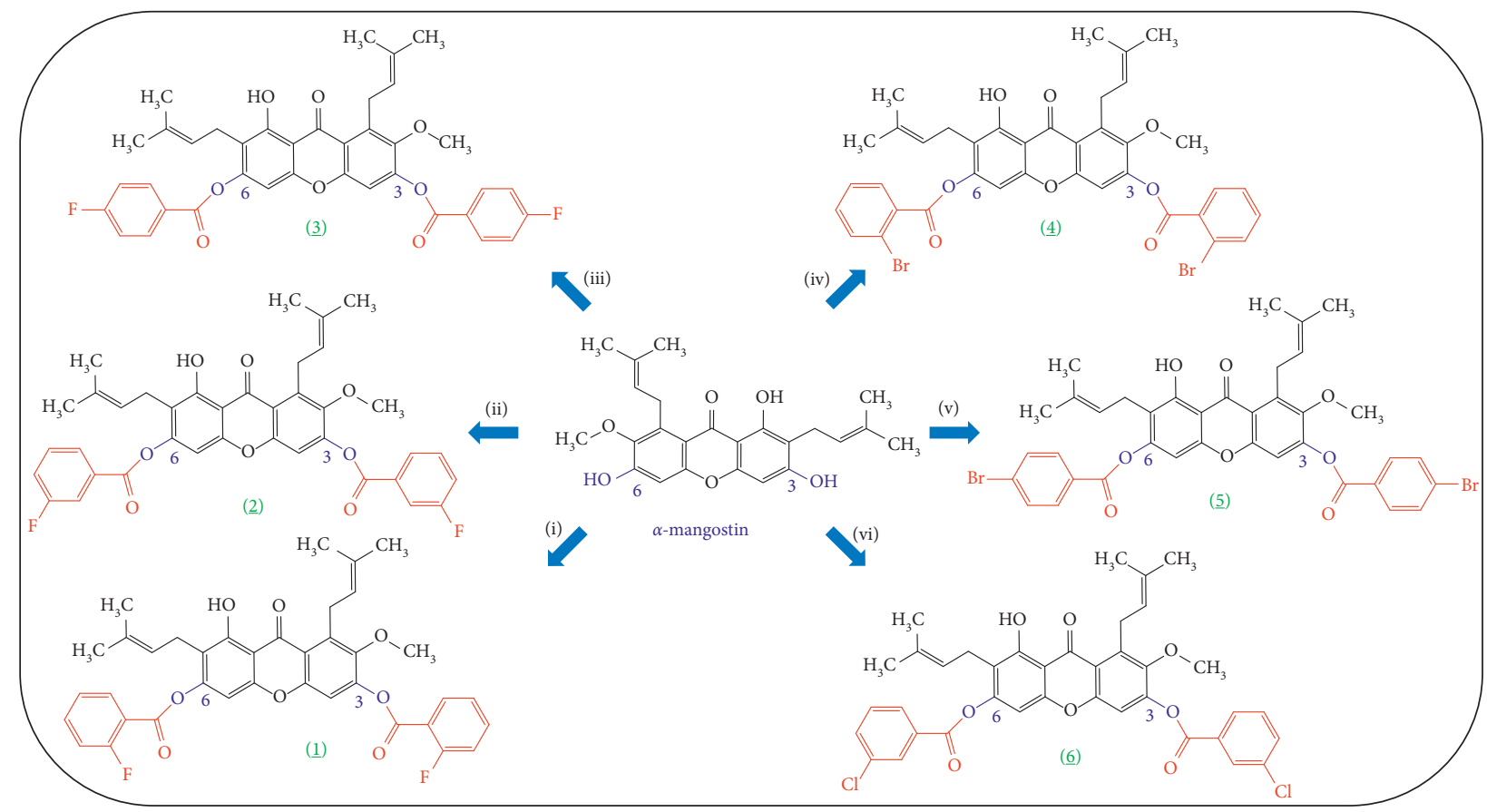

Figure 2: The scheme describes the synthesis of $\alpha$-MG derivatives from compounds 1 to 6 . Reagent and conditions: (i) 2-fluorobenzoyl chloride, $\mathrm{CH}_{2} \mathrm{Cl}_{2}, \mathrm{~N}\left(\mathrm{CH}_{3}\right)_{3}, 48 \mathrm{~h}$; (ii) 3-fluorobenzoyl chloride, $\mathrm{CH}_{2} \mathrm{Cl}_{2}, \mathrm{~N}\left(\mathrm{CH}_{3}\right)_{3}, 60$ h; (iii) 4-fluorobenzoyl chloride, $\mathrm{CH}_{2} \mathrm{Cl}_{2}, \mathrm{~N}\left(\mathrm{CH}_{3}\right)_{3}$, 55 h; (iv) 2-bromobenzoyl chloride, $\mathrm{CH}_{2} \mathrm{Cl}_{2}, \mathrm{~N}\left(\mathrm{CH}_{3}\right)_{3}, 50 \mathrm{~h}$; (v) 4-bromobenzoyl chloride, $\mathrm{CH}_{2} \mathrm{Cl}_{2}, \mathrm{~N}\left(\mathrm{CH}_{3}\right)_{3}$, 65 h; (vi) 3-chlorobenzoyl chloride, $\mathrm{CH}_{2} \mathrm{Cl}_{2}, \mathrm{~N}\left(\mathrm{CH}_{3}\right)_{3}, 50 \mathrm{~h}$.

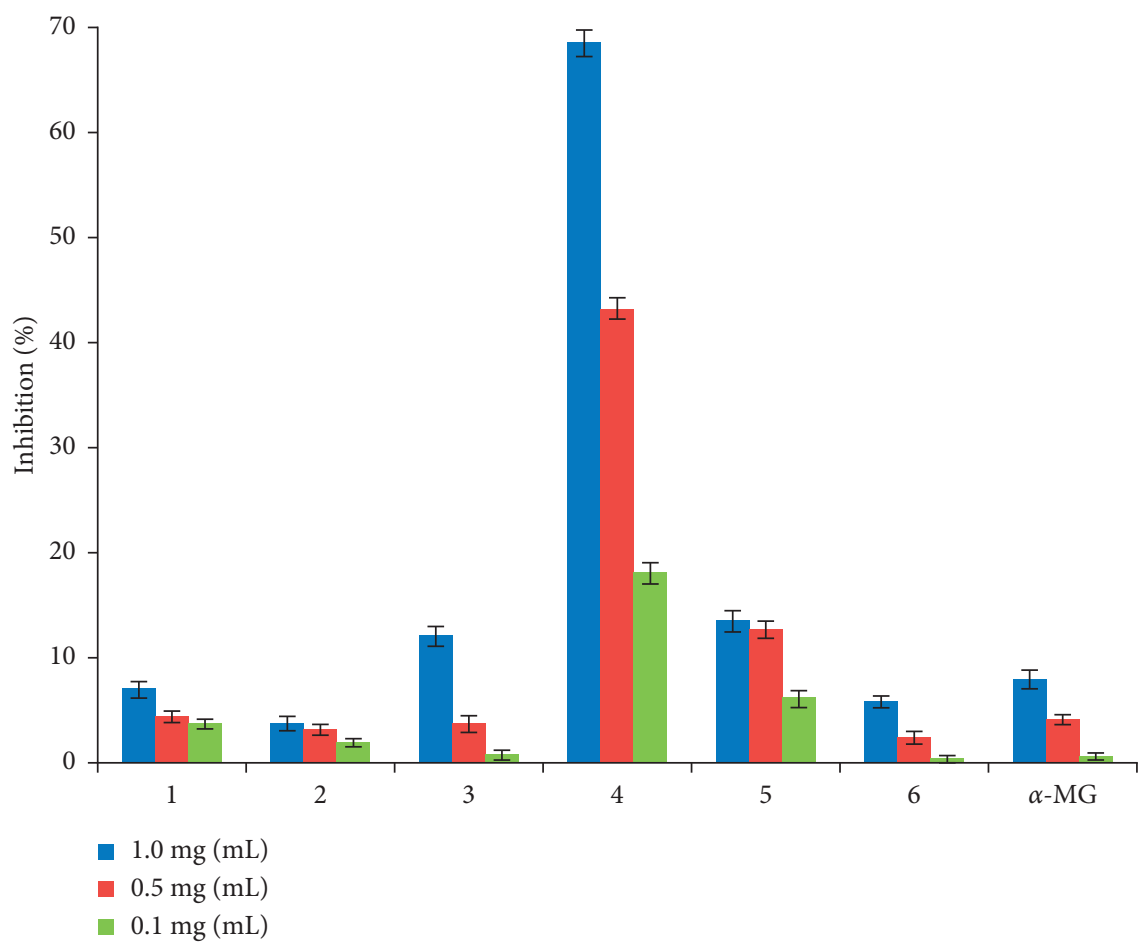

FIgUre 3: Antioxidant activities of $\alpha$-MG and its 6 derivatives $(1,2,3,4,5,6)$ at concentrations of $0.1,0.5$, and $1.0 \mathrm{mg} / \mathrm{mL}$. The antioxidant activities of $\alpha$-MG and its derivatives were investigated by using a 1,1-diphenyl-2-picrylhydrazyl (DPPH) assay.

3.4. Relationship between Structure and Anticancer Activity of $\alpha-M G$ Derivatives. To explore the relationship between structure and activity more thoroughly of $\alpha-\mathrm{MG}$ and its derivatives, we collected and compared the structure and cytotoxicity of $\alpha$-MG derivatives with the previous studies as shown in Table 1 . According to $\mathrm{Xu}$ et al., the cell viability 


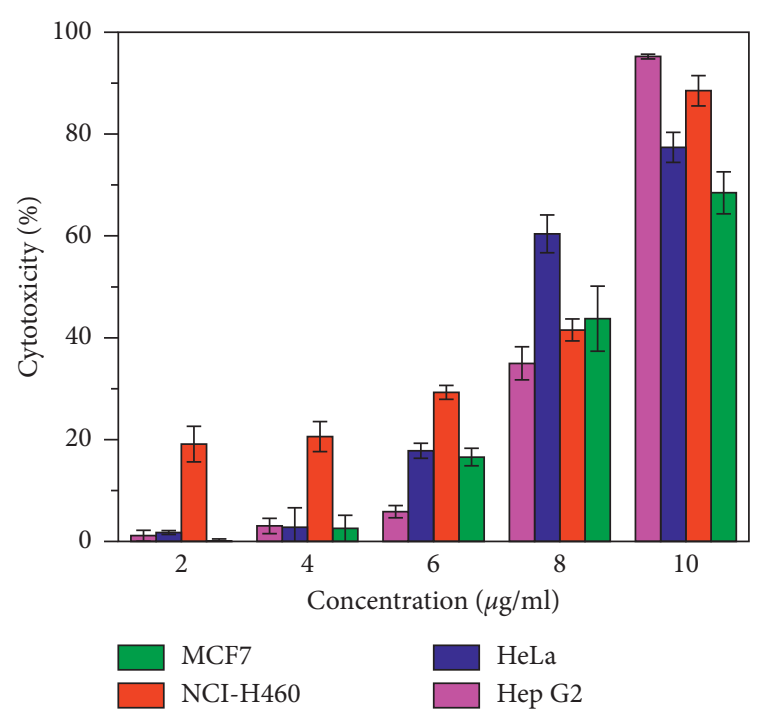

Figure 4: Cytotoxicity of compound (4) at different concentrations of $2,4,6,8$, and $10 \mu \mathrm{g} / \mathrm{mL}$ against 4 cancer cell lines of MCF-7, NCI-H460, HeLa, and Hep G2. The data are represented as mean \pm SD $(n=3)$.

inhibition in the HEY and A549 cells by 11-hydroxy-1isomangostin was investigated. 11-hydroxy-1-isomangostin, cyclization at $\mathrm{C}-15$, and $\mathrm{OH}$ of $\mathrm{C}-1$ from $\alpha$-MG weakly inhibited cell viabilities in HEY and A549 cells, where $\mathrm{IC}_{50}$ was greater than $20 \mu \mathrm{M}$ as discussed by Xu et al. [56]. In the case of 7-O-Demethyl mangostanin, cyclization at C-13 and $\mathrm{OH}$ of C-3 from $\alpha-\mathrm{MG}$ was intensively assessed the potential cytotoxic activity by Yang et al. 7-O-Demethyl mangostanin was tested by five cell lines U87 (malignant glioma), SGC7901 (gastric cancer), PC-3 (prostate cancer), H460 (lung cancer cell line), and PC12 (pheochromocytoma cell), and the half-maximal inhibitory concentration values were 6.39 , $8.09,6.21,7.84$, and $>50 \mu \mathrm{M}$, respectively [57]. The effect of $\beta$-mangostin and $\gamma$-mangostin on the growth of human colon cancer DLD- 1 cells was examined by Akao et al. $\beta$ mangostin, by adding methyl group at $\mathrm{O}$ group of $\mathrm{C}-3$, displayed weaker growth inhibitory effects than $\gamma$-mangostin in which the acetate group at C-7 was replaced by a hydroxyl group. From the values of $\mathrm{IC}_{50}, 8.1$ of $\beta$-mangostin, and 7.1 of $\gamma$-mangostin, the inhibitory activity was estimated for $\beta$-mangostin $<\gamma$-mangostin [58].

According to Ly et al., the same cytotoxic activity was for both cowanin and cowanol despite having different side chains at C-2. This demonstrated that the substitution of a methyl group at C-13 via a hydroxymethyl group did not impact the cytotoxicity. Besides, since both cowanin and cowanol are less active than $\alpha$-mangostin, the length of the alkyl side chains at C-2 or C-8 is significant as well [52]. Cowanin and cowanol have been very involved in decreasing the number of cells tested on MCF-7 cell lines by $15 \mathrm{mM}$ of $\mathrm{IC}_{50}$. Regarding DLD-1 cell lines, cowanin and cowanol showed the cytotoxicity of $\mathrm{IC}_{50}$ values around $18 \mathrm{mM}$. These $\mathrm{IC}_{50}$ values were approximately 2.5 times higher in DLD-1 cells than previously found by Nakagawa et al. [58].

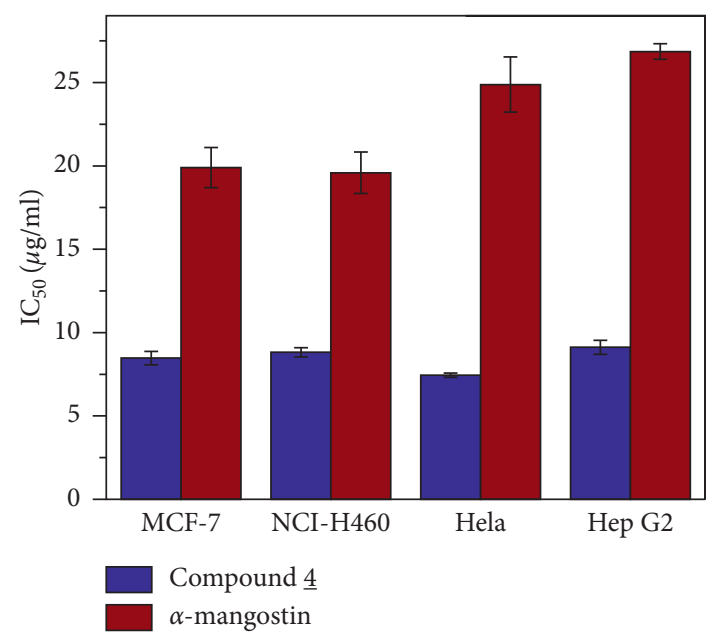

FIgURE 5: The $\mathrm{IC}_{50}$ value of compound 4 and $\alpha$-MG against four cancer cell lines of MCF-7, NCI-H460, HeLa, and Hep G2 for 48h. The data are represented as mean \pm SD $(n=3)$.

Chi et al. synthesized a novel compound (1b) by acetylation of $\alpha-\mathrm{MG}$ with $\mathrm{Ac}_{2} \mathrm{O}$ at $\mathrm{OH}$ of C-3 and C-6. Disubstitution of both C-3 and C-6 hydroxyl groups induces a complete decline in the cytotoxicity of $\alpha-\mathrm{MG}$ in the five cancer cell lines. However, the acetylation of $\alpha$-MG remained the cytotoxic activity. $\mathrm{IC}_{50}$ values in DLD- 1 cells HL-60, SMMC-7721, A-549, MCF-7, and SW480 were $11.92,13.56,11.60,16.65$, and 16.17 , respectively [59]. Chi et al. also synthesized the cyclization at $\mathrm{C}-12$ and $\mathrm{OH}$ of $\alpha$-MG (2k) (Table 1). The bromide substitution (compound 3e) was created, taking into account the vacant sites of $\alpha$-MG C- 4 and C-5 positions. $2 \mathrm{k}$ compound with mild antiproliferation activity against all the tested cancer cell lines is less toxic to five cell lines compared to $\alpha$-MG. The finding revealed that cyclization at $\mathrm{C}-12$ and $\mathrm{OH}$ of $\alpha-\mathrm{MG}$ is more sensitive to some cancer cells studied in vitro than normal cells and thus has good selectivity [59]. Besides, the biological effects of halogen were worth studying. The bromide substitution (compound $3 \mathrm{e}$ ) was created, taking into account the vacant sites of $\alpha$-MG C- 4 and C-5 positions. The effect of halogenation on 3e's selective potency is weak. The halogenated product exhibited better cytotoxicity; compound $3 \mathrm{e}$ in SMMC-7721 cell lines is up to three times more cytotoxic than $\alpha$-MG with an $\mathrm{IC}_{50}$ value of $3.98 \mu \mathrm{M}$ [59]. In the case of the isopropyl substitution compounds at C-6 to form isopropyl mangostin (IPM) and dimethyl substitution compounds at $\mathrm{OH}$ groups of C-3 and C-6 to generate Di-O-methyl mangostin (DMM), the cytotoxicity is not good. The $\mathrm{IC}_{50}$ in cervical cancer for IPM and DMM was 34.84 and 15.57, respectively, as discussed by Kirthanashri et al. [60].

In this work, $\alpha$-MG showed cytotoxic activity, manifested by the decrease of cell viability in four cancer cell lines at high concentrations. The $\mathrm{IC}_{50}$ values of $\alpha$-MG in MCF-7, NCI-H460, HeLa, and Hep G2 were corresponding to 48.47, $47.72,60.61$, and $65.48 \mu \mathrm{M}$, respectively. Significantly, the 2bromobenzoyl chloride substitution at C-3 and C- 6 of $\alpha$-MG (compound 4) indicated remarkable cytotoxicity. In detail, 
TABLE 1: The structure-activity relationship of $\alpha$-mangostin, its derivatives, and anticancer activity results.

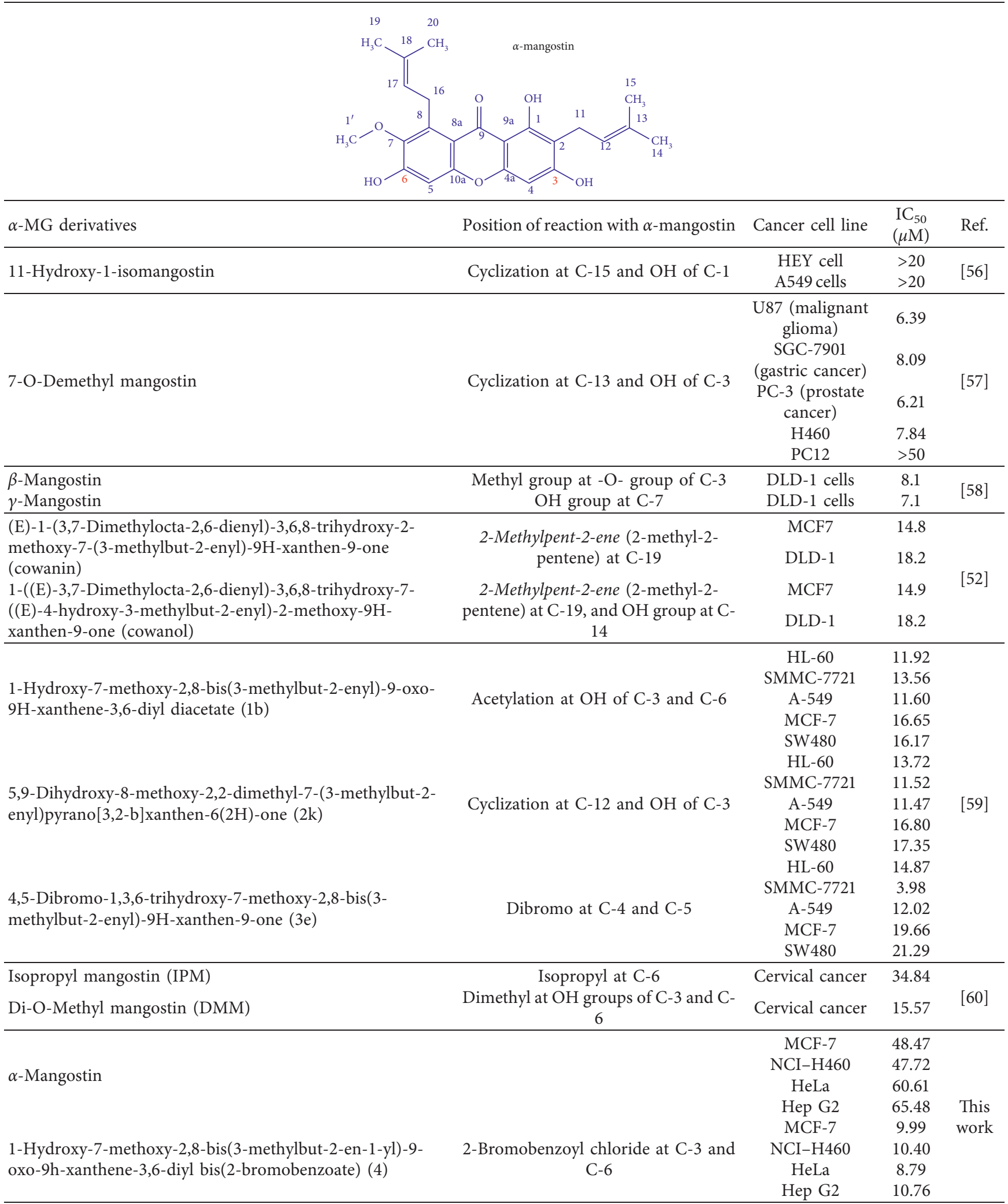

compound 4 is up to five or six times more cytotoxic than $\alpha$-MG with $\mathrm{IC}_{50}$ values of $8.79,9.99,10.40$, and $10.76 \mu \mathrm{M}$ for HeLa, MCF-7, NCI-H460, and Hep G2, respectively. The results suggest that acetylation at C-3 and C- 6 of $\alpha$-MG by halogen of benzoyl greatly improved cancer cell toxicity and promise as drugs in cancer therapy. 


\section{Conclusions}

In summary, we have successfully extracted pure $\alpha$-MG from mangosteen peels for the synthesis of $\alpha$-MG derivatives. The esterification reaction at positions of C-3 and C- 6 of $\alpha-\mathrm{MG}$ proved that the hydroxyl group $(-\mathrm{OH})$ at C-3 and C-6 plays an essential role for antioxidant and anticancer agents. Compound 4 exhibited the highest free radical scavenging $\mathrm{DPPH}$ activity $(68.7 \%$ at the concentration of $1 \mathrm{mg} / \mathrm{mL})$ compared to that of $\alpha-\mathrm{MG}$ and remaining derivatives. The result of the in vitro cytotoxicity study for the synthesized derivatives against four cancer cell lines MCF-7, NCI-H460, HeLa, and Hep G2 was significantly improved. Notably, compound 4 showed a significant enhancement of the antioxidant activity and the cytotoxicity toward MCF-7, NCI-H460, HeLa, and Hep G2 cell lines in comparison with pristine $\alpha$-MG at low concentration. In particular, the $\mathrm{IC}_{50}$ values of compound 4 exhibited five to six times lower than those of $\alpha$-MG for all tested cancerous cell lines after $48 \mathrm{~h}$. Our results provide new opportunities for further explorations of $\alpha$-MG derivatives for antioxidants and promises as drugs in cancer therapy. This result is the platform for a deeper research of the $\alpha-\mathrm{MG}$ for bioapplication.

\section{Data Availability}

Data supporting the results of our study can be found in supporting information.

\section{Conflicts of Interest}

The authors declare that there are no conflicts of interest regarding the publication of this article.

\section{Supplementary Materials}

Graphical Abstract. Figure S1: thin-layer chromatography (TLC) results of compounds 1, 2, 3, 4, 5, and 6 corresponding to reagent reaction of (i) 2-fluorobenzoyl chloride, (ii) 3-fluorobenzoyl chloride, (iii) 4-fluorobenzoyl chloride, (iv) 2-bromobenzoyl chloride, (v) 4-bromobenzoyl chloride, and (vi) 3-chlorobenzoyl chloride. TLC was carried out by the thin silica layer at different ratios of ethyl acetate:hexane. Figure S2: ${ }^{1} \mathrm{H}$-NMR spectra of $\alpha$-mangostin and its derivatives include compounds $1,2,3,4,5$, and 6 . Figure S3: ${ }^{13} \mathrm{C}$ NMR spectra of $\alpha$-mangostin derivatives include compounds 1, 2, 3, 4, 5, and 6. Figure S4: MS spectra of $\alpha$-mangostin derivatives include compounds $1,2,3,4,5$, and 6. Table S1: ${ }^{1} \mathrm{H}-\mathrm{NMR}$ data and chemical structure of $\alpha$-mangostin. Table S2: ${ }^{1} \mathrm{H}-\mathrm{NMR}$ and ${ }^{13} \mathrm{C}$-NMR data and chemical structure of compound 1 . Table S3: ${ }^{1} \mathrm{H}-\mathrm{NMR}$ and ${ }^{13} \mathrm{C}-\mathrm{NMR}$ data and chemical structure of compound 2 . Table S4: ${ }^{1} \mathrm{H}-\mathrm{NMR}$ and ${ }^{13} \mathrm{C}-\mathrm{NMR}$ data and chemical structure of compound 3. Table S5: ${ }^{1} \mathrm{H}-\mathrm{NMR}$ and ${ }^{13} \mathrm{C}-\mathrm{NMR}$ data and chemical structure of compound 4 . Table S6: ${ }^{1} \mathrm{H}-\mathrm{NMR}$ and ${ }^{13} \mathrm{C}-\mathrm{NMR}$ data and chemical structure of compound 5 . Table S7: ${ }^{1} \mathrm{H}-\mathrm{NMR}$ and ${ }^{13} \mathrm{C}-\mathrm{NMR}$ data and chemical structure of compound 6. Figure S5: cytotoxicity of $\alpha$-MG at different concentrations of $2,4,6,8$, and $10 \mu \mathrm{g} / \mathrm{mL}$ against 4 cancer cell lines of MCF-7, NCI-H460, HeLa, and Hep G2. The data are represented as mean $\pm \mathrm{SD} \quad(n=3)$. (Supplementary Materials)

\section{References}

[1] R. C. Fierascu, I. Fierascu, S. M. Avramescu, and E. Sieniawska, "Recovery of natural antioxidants from agroindustrial side streams through advanced extraction techniques," Molecules, vol. 24, no. 23, p. 4212, 2019.

[2] W. Suttirak and S. Manurakchinakorn, "In vitro antioxidant properties of mangosteen peel extract," Journal of Food Science \& Technology, vol. 51, no. 12, pp. 3546-3558, 2014.

[3] V. Anh Tran, K. B. Vu, T.-T. Thi Vo et al., "Experimental and computational investigation on interaction mechanism of Rhodamine $\mathrm{B}$ adsorption and photodegradation by zeolite imidazole frameworks-8," Applied Surface Science, vol. 538, p. $148065,2021$.

[4] V. A. Tran and S.-W. Lee, "pH-triggered degradation and release of doxorubicin from zeolitic imidazolate framework-8 (ZIF8) decorated with polyacrylic acid," RSC Advances, vol. 11, no. 16, pp. 9222-9234, 2021.

[5] A. Teixeira, N. Baenas, R. Dominguez-Perles et al., "Natural bioactive compounds from winery by-products as health promoters: a review," International Journal of Molecular Sciences, vol. 15, no. 9, pp. 15638-15678, 2014.

[6] N. Y. T. Tran, N. P. T. Nhan, V. T. Thanh et al., "Effect of storage condition on color, vitamin $\mathrm{C}$ content, polyphenol content and antioxidant activity in fresh soursop pulp (Annona muricata L.)," IOP Conference Series: Materials Science and Engineering, vol. 736, p. 22065, 2020.

[7] T. Nhut Pham, D.-V. N. Vo, T. Duc Lam et al., "Preparation and determination of total anthocyanins extraction from the skin of vigna cylindrica skeels (Dolichos catjang Burm.f)," IOP Conference Series: Materials Science and Engineering, vol. 542, p. 012037, 2019.

[8] V. A. Tran, T. P. Nguyen, V. T. Le, I. T. Kim, S.-W. Lee, and C. T. Nguyen, "Excellent photocatalytic activity of ternary Ag@WO3@rGO nanocomposites under solar simulation irradiation," Journal of Science: Advanced Materials and Devices, vol. 6, no. 1, pp. 108-117, 2021.

[9] V. A. Tran, V. G. Vo, K. Shim, S.-W. Lee, and S. S. A. An, "Multimodal mesoporous silica nanocarriers for dual stimuliresponsive drug release and excellent photothermal ablation of cancer cells," International Journal of Nanomedicine, vol. 15, pp. 7667-7685, 2020.

[10] E. R. S. F. J. Barba, M. Brncic, and J. M. L. Rodriquez, "green extraction and valorization of by-products from food processing," CRC Press, vol. 1, no. 1, p. 384, 2019.

[11] T. Hien Tran, V. Tien Nguyen, T. Phat Dao et al., "New direction in research on extraction of Citrus aurantifolia (Lemon fruit) essential oil grown in Mekong Delta-Vietnam via microwave-assisted hydrodistillation," IOP Conference Series: Materials Science and Engineering, vol. 542, p. 12038, 2019.

[12] V. A. Tran, N. H. T. Tran, L. G. Bach et al., "Facile synthesis of propranolol and novel derivatives," Journal of Chemistry, vol. 2020, Article ID 9597426, 10 pages, 2020.

[13] W. Widowati, D. R. Laksmitawati, T. L. Wargasetia et al., "Mangosteen peel extract (Garcinia mangostana L.) as protective agent in glucose-induced mesangial cell as in vitro model of diabetic glomerulosclerosis," Iranian Journal of Basic Medical Sciences, vol. 21, no. 9, pp. 972-977, 2018. 
[14] P. da Silva Machado, R. da Silva Melo, A. B. S. Araújo et al., "Bioactive and functional compounds of mixed beverages based on fruits and vegetables," SN Applied Sciences, vol. 2, no. 5 , p. $810,2020$.

[15] T. Nhut Pham, T. Quoc Toan, T. Duc Lam et al., "Anthocyanins extraction from Purple Sweet Potato (Ipomoea batatas (L.) Lam): the effect of $\mathrm{pH}$ values on natural color," IOP Conference Series: Materials Science and Engineering, vol. 542, p. 012031, 2019.

[16] S. B. Nimse and D. Pal, "Free radicals, natural antioxidants, and their reaction mechanisms," RSC Advances, vol. 5, no. 35, pp. 27986-28006, 2015.

[17] J. Wang, Y. Li, Y. Yang et al., "A new strategy for deleting animal drugs from traditional Chinese medicines based on modified yimusake formula," Scientific Reports, vol. 7, no. 1, p. 1504, 2017.

[18] H. Yuan, Q. Ma, L. Ye, and G. Piao, "The traditional medicine and modern medicine from natural products," Molecules, vol. 21, no. 5, p. 559, 2016.

[19] F. Yi, L. Li, L. J. Xu et al., "In silico approach in reveal traditional medicine plants pharmacological material basis," Chinese Medicine, vol. 13, no. 1, p. 33, 2018.

[20] G. Chen, Y. Li, W. Wang, and L. Deng, "Bioactivity and pharmacological properties of $\alpha$-mangostin from the mangosteen fruit: a review," Expert Opinion on Therapeutic Patents, vol. 28, no. 5, pp. 415-427, 2018.

[21] B. Nabilah, W. I. Wan Zunairah, M. Nor Afizah, and Z. A. Nur Hanani, "Effect of mangosteen (Garcinia mangostana L.) pericarp extract on the different carriers for antioxidant active packaging films," Journal of Packaging Technology and Research, vol. 3, no. 2, pp. 117-126, 2019.

[22] G. Y. T. Tan, W. Zimmermann, K.-H. Lee, J. C.-W. Lan, H. S. Yim, and H. S. Ng, "Recovery of mangostins from Garcinia mangostana peels with an aqueous micellar biphasic system," Food and Bioproducts Processing, vol. 102, pp. 233240, 2017

[23] S. Lin, W. L. W. Sin, J.-J. Koh et al., "Semisynthesis and biological evaluation of xanthone amphiphilics as selective, highly potent antifungal agents to combat fungal resistance," Journal of Medicinal Chemistry, vol. 60, no. 24, pp. 1013510150, 2017.

[24] J. J. Wang, B. J. S. Sanderson, and W. Zhang, "Cytotoxic effect of xanthones from pericarp of the tropical fruit mangosteen (Garcinia mangostana Linn.) on human melanoma cells," Food and Chemical Toxicology, vol. 49, no. 9, pp. 2385-2391, 2011.

[25] A.-V. Tran, K. Shim, T.-T. Vo Thi, J.-K. Kook, S. S. A. An, and S.-W. Lee, "Targeted and controlled drug delivery by multifunctional mesoporous silica nanoparticles with internal fluorescent conjugates and external polydopamine and graphene oxide layers," Acta Biomaterialia, vol. 74, pp. 397-413, 2018.

[26] V. A. Tran and S.-W. Lee, "A prominent anchoring effect on the kinetic control of drug release from mesoporous silica nanoparticles (MSNs)," Journal of Colloid and Interface Science, vol. 510, pp. 345-356, 2018.

[27] E.-B. Lim, T. A. Vy, and S.-W. Lee, "Comparative release kinetics of small drugs (ibuprofen and acetaminophen) from multifunctional mesoporous silica nanoparticles," Journal of Materials Chemistry B, vol. 8, no. 10, pp. 2096-2106, 2020.

[28] M. M. Ashton, O. M. Dean, A. J. Walker et al., "The therapeutic potential of mangosteen pericarp as an adjunctive therapy for bipolar disorder and schizophrenia," Frontiers in Psychiatry, vol. 10, no. 115, p. 115, 2019.
[29] J. M. Pérez-Rojas, R. González-Macías, J. González-Cortes, R. Jurado, J. Pedraza-Chaverri, and P. García-López, "Synergic effect of $\alpha$-mangostin on the cytotoxicity of cisplatin in a cervical cancer model," Oxidative Medicine and Cellular Longevity, vol. 2016, Article ID 7981397, 13 pages, 2016.

[30] W. Suthammarak, P. Numpraphrut, R. Charoensakdi et al., "Antioxidant-enhancing property of the polar fraction of mangosteen pericarp extract and evaluation of its safety in humans," Oxidative Medicine and Cellular Longevity, vol. 2016, Article ID 1293036, 10 pages, 2016.

[31] A. Shagufta and I. Ahmad, "Recent insight into the biological activities of synthetic xanthone derivatives," European Journal of Medicinal Chemistry, vol. 116, pp. 267-280, 2016.

[32] M. Pedro, F. Cerqueira, M. E. Sousa, M. S. J. Nascimento, and M. Pinto, "Xanthones as inhibitors of growth of human cancer cell lines and their effects on the proliferation of human lymphocytes in vitro," Bioorganic \& Medicinal Chemistry, vol. 10, no. 12, pp. 3725-3730, 2002.

[33] R. A. P. Castanheiro, M. M. M. Pinto, A. M. S. Silva et al., "Dihydroxyxanthones prenylated derivatives: synthesis, structure elucidation, and growth inhibitory activity on human tumor cell lines with improvement of selectivity for MCF-7," Bioorganic \& Medicinal Chemistry, vol. 15, no. 18, pp. 6080-6088, 2007.

[34] D. Xu, Y. Nie, X. Liang et al., "A concise and efficient total synthesis of alpha-mangostin and beta-mangostin from Garcinia mangostana," Natural Product Communications, vol. 8, no. 8, pp. 1101-1103, 2013.

[35] X. Fei, M. Jo, B. Lee et al., "Synthesis of xanthone derivatives based on $\alpha$-mangostin and their biological evaluation for anticancer agents," Bioorganic \& Medicinal Chemistry Letters, vol. 24, no. 9, pp. 2062-2065, 2014.

[36] H. H. Kwak, I. R. Kim, H. J. Kim, B. S. Park, and S. B. Yu, " $\alpha$-Mangostin induces apoptosis and cell cycle arrest in oral squamous cell carcinoma cell," Evidence-based Complementary and Alternative Medicine: eCAM, vol. 2016, Article ID 5352412, 10 pages, 2016.

[37] J. Markowicz, Ł. Uram, J. Sobich, L. Mangiardi, P. Maj, and W. Rode, "Antitumor and anti-nematode activities of $\alpha$-mangostin,” European Journal of Pharmacology, vol. 863, p. 172678, 2019.

[38] D. Xu, Y. Nie, X. Liang et al., "A concise and efficient total synthesis of alpha-mangostin and beta-mangostin from Garcinia mangostana," Natural Product Communications, vol. 8, no. 8, pp. 1101-1103, 1101.

[39] X. Fei, M. Jo, B. Lee et al., "Synthesis of xanthone derivatives based on alpha-mangostin and their biological evaluation for anti-cancer agents," Bioorganic \& Medicinal Chemistry Letters, vol. 24, no. 9, pp. 2062-2065, 1016.

[40] Z. Hajdú, N. Jedlinszki1, and J. Hohmann, "Xanthine oxidaseinhibitory activity and antioxidant properties of the methanol extract and flavonoids of artemisia asiatica," Records of Natural Products, vol. 8, no. 3, pp. 299-302, 2014.

[41] R. Kandiyoti, A. Herod, K. Bartle, and T. Morgan, "Analytical techniques for high-mass materials," in Solid Fuels and Heavy Hydrocarbon Liquids, R. Kandiyoti, A. Herod, K. Bartle, and T. Morgan, Eds., Elsevier, Amsterdam, Netherlands, Second edition, 2017.

[42] S. Tian, W. Liu, F. Liu, X. Zhang, and H. Upur, "Development and validation of an high-performance liquid chromatography-diode array detector method for the simultaneous determination of six phenolic compounds in abnormal savda munziq decoction," Pharmacognosy Magazine, vol. 11, no. 41, pp. 157-162, 2015. 
[43] K. Bundeesomchok, A. Filly, N. Rakotomanomana, P. Panichayupakaranant, and F. Chemat, "Extraction of $\alpha$-mangostin from Garcinia mangostana L. using alternative solvents: computational predictive and experimental studies," Lebensmittel-Wissenschaft und-Technologie-Food Science and Technology, vol. 65, pp. 297-303, 2016.

[44] N. A. Mohammad, D. N. Abang Zaidel, I. I. Muhamad, M. Abdul Hamid, H. Yaakob, and Y. M. Mohd Jusoh, "Optimization of the antioxidant-rich xanthone extract from mangosteen (Garcinia mangostana L.) pericarp via microwave-assisted extraction," Heliyon, vol. 5, no. 10, p. e02571, 2019.

[45] V. Vichai and K. Kirtikara, "Sulforhodamine B colorimetric assay for cytotoxicity screening," Nature Protocols, vol. 1, no. 3, pp. 1112-1116, 2006.

[46] V. K. Sodde, R. Lobo, N. Kumar, R. Maheshwari, and C. S. Shreedhara, "Cytotoxic activity of Macrosolen parasiticus (L.) Danser on the growth of breast cancer cell line (MCF-7)," Pharmacognosy Magazine, vol. 11, no. 1, pp. S156-S160, 2015.

[47] V. A. Tran, A. N. Kadam, and S.-W. Lee, “Adsorption-assisted photocatalytic degradation of methyl orange dye by zeoliteimidazole-framework-derived nanoparticles," Journal of Alloys and Compounds, vol. 835, p. 155414, 2020.

[48] J.-J. Koh, H. Zou, D. Mukherjee et al., "Amphiphilic xanthones as a potent chemical entity of anti-mycobacterial agents with membrane-targeting properties," European Journal of Medicinal Chemistry, vol. 123, pp. 684-703, 2016.

[49] J.-J. Koh, H. Zou, S. Lin et al., "Nonpeptidic amphiphilic xanthone derivatives: structure-activity relationship and membrane-targeting properties," Journal of Medicinal Chemistry, vol. 59, no. 1, pp. 171-193, 2016.

[50] J.-J. Koh, S. Lin, T. T. Aung et al., "Amino acid modified xanthone derivatives: novel, highly promising membraneactive antimicrobials for multidrug-resistant Gram-positive bacterial infections," Journal of Medicinal Chemistry, vol. 58, no. 2, pp. 739-752, 2015.

[51] K. Matsumoto, Y. Akao, H. Yi et al., "Preferential target is mitochondria in $\alpha$-mangostin-induced apoptosis in human leukemia HL60 cells," Bioorganic \& Medicinal Chemistry, vol. 12, no. 22, pp. 5799-5806, 2004.

[52] L. D. Ha, P. E. Hansen, O. Vang, F. Duus, H. D. Pham, and L.-H. D. Nguyen, "Cytotoxic geranylated xanthones and O-alkylated derivatives of ALPHA.-Mangostin," Chemical and Pharmaceutical Bulletin, vol. 57, no. 8, pp. 830-834, 2009.

[53] Z.-M. Yang, J. Huang, J.-K. Qin et al., "Design, synthesis and biological evaluation of novel 1-hydroxyl-3-aminoalkoxy xanthone derivatives as potent anticancer agents," European Journal of Medicinal Chemistry, vol. 85, pp. 487-497, 2014.

[54] K. Pavithra and S. Vadivukkarasi, "Evaluation of free radical scavenging activity of various extracts of leaves from Kedrostis foetidissima (Jacq.) Cogn," Food Science and Human Wellness, vol. 4, no. 1, pp. 42-46, 2015.

[55] S. W. Leong, S. M. Mohd Faudzi, F. Abas et al., "Nitric oxide inhibitory activity and antioxidant evaluations of 2-benzoyl6-benzylidenecyclohexanone analogs, a novel series of curcuminoid and diarylpentanoid derivatives," Bioorganic \& Medicinal Chemistry Letters, vol. 25, no. 16, pp. 3330-3337, 2015.

[56] X.-H. Xu, Q.-Y. Liu, T. Li et al., "Garcinone E induces apoptosis and inhibits migration and invasion in ovarian cancer cells," Scientific Reports, vol. 7, no. 1, p. 10718, 2017.

[57] R. Yang, P. Li, N. Li et al., "Xanthones from the pericarp of Garcinia mangostana," Molecules, vol. 22, no. 5, 2017.
[58] Y. Akao, Y. Nakagawa, and Y. Nozawa, "Anti-cancer effects of xanthones from pericarps of mangosteen," International Journal of Molecular Sciences, vol. 9, no. 3, pp. 355-370, 2008.

[59] X.-Q. Chi, C.-T. Zi, H.-M. Li et al., "Design, synthesis and structure-activity relationships of mangostin analogs as cytotoxic agents," RSC Advances, vol. 8, no. 72, pp. 41377-41388, 2018.

[60] S. V. Kirthanashri, N. R. Kumar, and S. Chitra, "Anti-cancer activity of Garcinia mangostana L. And its derivatives in cervical cancer," Asian Journal of Research in Biochemistry, vol. 6, no. 4, pp. 21-30, 2020. 